Journal of Biotechnology and Strategic Health Research

\author{
Derleme / Review
}

http://dergipark.org.tr/tr/pub/bshr

\title{
Living With COVID-19 Is A Reality Among Dental Fraternity: A Reflection
}

\author{
Diş Hekimliğinde COVID-19 İle Yaşamak Gerçeği: Bir Yansıma
}

\author{
(iD) Muhd Firdaus Che Musa ${ }^{1}$, iD Syarifah Haizan Binti Sayed Kamar', \\ iD Yang Rafidah Hassan ${ }^{2}$
}

\begin{abstract}
${ }^{1}$ Kulliyyah of Dentistry, International Islamic University Malaysia, Dep. of Paediatric Dentistry and Dental Public Health, Pahang, Malaysia ${ }^{2}$ Ministry of Health Malaysia, Specialist Clinic of Orthodontics, Sungai Petani Dental Clinic, Kedah, Malaysia

ORCID ID: Muhd Firdaus Che Musa https://orcid.org/0000-0003-0208-5207,

Syarifah Haizan Binti Sayed Kamar https://orcid.org/0000-0002-3826-5712, Yang Rafidah Hassan https://orcid.org/0000-0001-6972-3379,

^Sorumlu Yazar / Corresponding Author: Asst. Prof Dr Muhd Firdaus bin Che Musa, e-posta / e-mail: muhdfirdaus83@gmail.com

Geliş Tarihi / Received : 15-02-2021 Kabul Tarihi / Accepted: 18-03-2021 Yayın Tarihi / Online Published: 30-04-2021

Che Musa M.F., Kamar S.H.S., Hassan Y.R. Living with Covid-19 is a reality among dental fraternity: A reflection,

J Biotechnol and Strategic Health Res. 2021;5(1):8-11
\end{abstract}

This paper aims to deliberately discuss the impact of the COVID-19 pandemic on the dental fraternity, specifically on how dentistry is practiced, and at the same time to rethink the future of dentistry. It is undeniably that the pandemic has affected a country's economy, and it has negatively influenced people's behavior in seeking and maintaining their dental health. Concern has been raised on whether it is safe to visit dental facilities. Several guidelines based on the latest evidence provided by local regulatory authorities to educate and ensure the dental practitioners practice strict precautionary and selective case evaluation approaches. Treatments to patients with symptoms of COVID-19 should be delayed and referred to the relevant healthcare providers. This will encourage the public to seek high quality and safe dental care. Nevertheless, the current changes to practice and restrictions on aerosol-generating procedures provide an opportunity to re-orientate dental care towards a less invasive and more preventive approach, expansion of dental workforce roles and responsibilities and working together in a team to tackle and control the pandemic. A radical reform of oral healthcare systems is therefore requiring a bold decision-making from our political and dental industry leaders.

Keywords COVID-19; dental; Malaysia; safe; healthcare

Öz

Bu makale, COVID-19 salgınının diş hekimliği mesleği üzerindeki etkisini, özellikle diş hekimliğinin nasıl uygulandığını kasıtlı olarak tartıșmayı ve aynı zamanda diş hekimliğinin geleceğini yeniden düşünmeyi amaçlamaktadır. Salgının bir ülkenin ekonomisini etkilediği ve insanların diş sağlıklarını arama ve sürdürmedeki davranışların olumsuz etkilediği inkar edilemez. Diş hekimliği tesislerini ziyaret etmenin güvenli olup olmadığı konusunda endişeler artmıştır. Diş hekimlerinin sıkı ihtiyati ve seçici vaka değerlendirme yaklaşımlarını uygulamalarımı sağlamak ve eğitmek için yerel düzenleyici makamlar tarafından sağlanan en son kantlara dayanan birkaç kılavuz. COVID-19 semptomları olan hastalara yapılan tedaviler ertelenmeli ve ilgili sağhlk hizmeti sağlayıcılarına yönlendirilmelidir. Bu, halkı yüksek kaliteli ve güvenli diş bakımı aramaya teşvik edecektir. Bununla birlikte, pandemi, aerosol üreten prosedürler üzerindeki uygulamadaki mevcut değişiklikler ve kısttlamalar, diş bakımını daha az invazif ve daha önleyici bir yaklaşıma doğru yeniden yönlendirme, diş hekimliği iş gücü rollerinin ve sorumluluklarının genişletilmesi ve bunların üstesinden gelmek ve kontrol etmek için bir ekipte birlikte çalışmak için bir firsat sağlar. Bu nedenle ağız sağlı̆̆ sistemlerinde radikal bir reform, politik ve diş hekimliği endüstrisi cesur bazı kararlar almayı gerektiriyor.

Anahtar

Kelimeler

COVID-19; Diş Hekimliği; Malezya; güvenlik; sağllk 


\section{INTRODUCTION}

The year 2020 is an unforgettable, tough year for everyone. The identification of a new, tiny, yet contagious SARSCoV-2 coronavirus in $2019^{1,2}$ has caused a worldwide lockdown which has a huge impact, particularly on a country's economy, social, and people's emotional well-being. ${ }^{3.4}$ It has been said that pandemics are lived forward and understood backwards. The COVID-19 pandemic is no exception, and living with COVID-19 virus is becoming a reality among the public and dental fraternity., The pandemic has a significant impact on patients and dental professionals. ${ }^{6,7}$

The outbreak has negatively influenced people's behavior to seek and maintain their general and dental health. ${ }^{1,6}$ During this period, there is limited access to dental care. ${ }^{6,8}$ Most people take 'wait and see' approach in dealing with their dental problems and only seek care when the symptoms become unbearable or affecting their daily lives. This situation could be due to their concern on whether it is safe to seek dental treatments during this pandemic era. Undoubtedly, this situation could lead to the exacerbation of dental conditions and lead to more serious issues and unnecessary tooth loss. ${ }^{6-8}$ Moreover, due to economic and social restriction, it further widening oral health inequalities. ${ }^{910}$ Considering there are great needs and demands for dental care, ${ }^{5,6,8}$ it is important to and find a sustainable way forward to embrace the new way of living with the virus. This is particularly important to reassuring the public to encourage them to seek high quality and safe dental care. ${ }^{6,10}$

Dentists around the world have been treating patients during the pandemic for nearly a year. In the early phase of the pandemic, regulatory guidelines recommended that dental professionals only provide emergency and non-aerosol-generating procedures (non-AGP) to patients. ${ }^{5,6,10}$ In this case, dental professionals would only attend dental emergencies like swelling, uncontrollable pain, bleeding, infection, trauma to teeth or bones, as well as any other conditions that could be harmful without immediate care.? It has been acknowledged that strict infection control and minimal touch dentistry are the keys in preventing dental operatory contamination. ${ }^{2,5}$ Despite cases in other countries where asymptomatic COVID-19 patients sought dental care without knowing they were infected, there is yet any reported clusters of airborne diseases, including COVID-19 to spread during dental procedures. ${ }^{11}$ This could be due to the strict precautionary and selective case evaluation undertaken by dental professionals. This report is backed by a new study published in one of the world's leading medical journal, The Lancet, in August 2020. ${ }^{5}$

In Malaysia, clinicians attending patients should follow the local regulatory authorities' guidelines, ${ }^{12}$ specifically from the Oral Health Program (OHP), Ministry of Health Malaysia (MOH). ${ }^{13}$ These guidelines include using the use of appropriate standard Personal Protecting Equipment (PPE) and maintaining efficient air circulation and ventilation. Dental treatments should be minimally invasive, requires minimal contact, and have no or limited aerosol contact. Patients should be informed about changes in the treatment procedures and the cost of treatments as part of the COVID-19 control measures. The clinic disinfection protocols during pre-, during, and post-treatment will be strictly followed. Treatments to patients with symptoms of COVID-19 should be deferred, and they should be referred to as the COVID-19 screening unit. The followed recommendation needs to be refined based on the latest evidence and rigorously evaluated by experts during the crisis. ${ }^{13}$ At the time this paper is written, all dental procedures are allowed, including the AGP. However, COVID pre-screening assessment and strict precautionary approaches were undertaken before starting any dental procedures, based on the patient's risk status and locality.

Before making a dental appointment, an initial telephone triage could be conducted to assess patients' COVID risk status, vulnerability and their potential threat to the dental team, other patients, and their companions. ${ }^{6}$ Further- 
more, medical professionals will refer to the MySejahtera app developed by the Ministry of Health (MOH), which provides live national tracking of reported cases to track COVID-19 cases and identify high-risk Covid-19 infection areas. A virtual triage using photos, videos, and video-calling can also help dental professionals screen and prioritize actual dental emergencies requiring immediate attention. Nevertheless, this process requires careful planning as it may have implications in terms of the existing law and regulations.

Based on the recent events, we can see that the globalized life has become indefensible, and our healthcare systems are not prepared for the next pandemic. As we try to move forward, there is a possibility that our lives will be significantly different from the one we had before the Covid-19 pandemic. ${ }^{4}$ Nevertheless, there is a light at the end of the coronavirus tunnel. The COVID-19 pandemic might be ending soon with the possibility of global mass vaccination roll-out. ${ }^{4,14}$ However, it is important to note that vaccination only provides a reliable approach to control the pandemic rather than providing a cure for the disease $e^{3,4}$ In this point of time, our survival will depend on our current actions. Hence, we still need to practice social distancing measures to reduce the spread of the disease.

Moreover, as the upstream approach of movement control order (MCO) is no longer applicable due to economic restriction, we are now highly dependent on the downstream approach, "We Take Care of Our Own". There is a lot of work to be done, especially in bringing awareness to the public and making people re-evaluate our life priorities, including in general and oral health. Besides, given that movement restrictions may interrupt and compromise their chosen way of living and quality of life, it is crucial to find a holistic way to accommodate Malaysians' needs to maintain their social relationships, thus enhancing their psychosocial well-being. In this regard, while we will continue living our lives, our lives will be significantly different post-pandemic. ${ }^{15}$ We should revisit our priorities and find a holistic and sustainable way forward to embrace living with the virus, while consistently seeking quality of life; both in general and dental healthcare, by renewing our interpretation of life norms.

Current restrictions on aerosol-generating procedures provide an opportunity to rethink the future of dentistry, ${ }^{6,7}$ focusing on re-orientating the dental care towards a less invasive and more preventive approach. ${ }^{10}$ In addition to that, we must also work collaboratively to tackle the shared risks for oral diseases and other non-communicable diseases. ${ }^{16}$ Health professionals and the public should find the best approach to meet patients' oral health care needs and demands while maintaining safe dental practices in this COVID 19 era. More public inputs and discussions on public health should be considered to provide the best health care. The existing dental care system needs to be more responsive and prioritize care for vulnerable groups with a high need for care.

In addition, the contribution of the wide cadres of the dental workforce, including supporting dental staff in controlling and preventing this pandemic through an effective team-working approach should also be acknowledged. They should also be given a privilege and an opportunity to expand their knowledge and skills in managing infectious diseases. As such, radical reform in the oral healthcare system requires brave and bold decision-making from our political and industry leaders. 
J Biotechnol and Strategic Health Res. 2021;5(1):8-11

\section{References}

1. 1.Chau NVV, Thanh Lam V, Thanh Dung N, Yen LM, Minh NNQ, Hung LM, et al. The natural history and transmission potential of asymptomatic SARS-CoV-2 infection. Clin Infect Dis. 2020;21:234-240 https://doi.org/10.1093/cid/ciaa711

2. Sakurai A, Sasaki T, Kato S, Hayashi M, Tsuzuki SI, Ishihara T, et al. Natural History of Asymptomatic SARS-CoV-2 Infection. N Engl J Med. 2020;383(9):885-6. 10.1056/NEJMc2013020

3. Duke Global Health Institute. Will Low-Income Countries Be Left Behind When COVID-19 Vaccines Arrive? Durham, NC: Duke Global Health Institute,; 2020 [Available from: https://globalhealth.duke.edu/news/will-low-income-countries-be-left-behind-when-covid-19-vaccines-arrive.

4. Lopez G. The Covid-19 vaccine's 2 big challenges. US Vox Media. 2020.

5. Epstein JB, Chow K, Mathias R. Dental procedure aerosols and COVID-19. The Lancet: Infectious Diseases. 2021 Apr;21(4):e73. 10.1016/S1473-3099(20)30636-8

6. Passarelli PC, Rella E, Manicone PF, Garcia-Godoy F, D'Addona A. The impact of the COVID-19 infection in dentistry. Exp Biol Med (Maywood). 2020;245(11):940-4. DOI: $10.1177 / 1535370220928905$

7. Guo H, Zhou Y, Liu X, Tan J. The impact of the COVID-19 epidemic on the utilization of emergency dental services. J Dent Sci. 2020 Dec;15(4):564-567. doi: 10.1016/j. jds.2020.02.002.

8. Ahmadi H, Ebrahimi A, Ghorbani F. The impact of COVID-19 pandemic on dental practice in Iran: a questionnaire-based report. BMC Oral Health. 2020;20(1):354. doi: 10.1186/s12903-020-01341-x.
9. Marmot M. Society and the slow burn of inequality. Lancet. 2020;395(10234):1413-4. doi: 10.1016/S0140-6736(20)30940-5.

10. Watt RG. COVID-19 is an opportunity for reform in dentistry. The Lancet. 2020;396:462. doi: 10.1016/S0140-6736(20)31529-4.

11. Wilson NM, Norton A, Young FP, Collins DW. Airborne transmission of severe acute respiratory syndrome coronavirus- 2 to healthcare workers: a narrative review. Anaesthesia. 2020;75(8):1086-95. doi: 10.1111/anae.15093.

12. Che Musa MF, Hassan YF, Sayed Kamar SH, Abllah Z, Supa'at S, Rahman F, et al. Situation, challenges and potential reforms for healthcare systems of Malaysia and Bangladesh: overview of dental counterpart. Journal of Biotechnology and Strategic Health Research 2019;3(3):225-36. DOI: 10.34084/bshr.716345

13. Oral Health Programme Malaysia. Guidelines COVID-19 Management No.5/2020. In OHP MoHM, editor. Putrajaya 2020.

14. Win TL. How vaccines can reach the world's poorest 2020 4/01/2020. Available from: https://www.weforum.org/agenda/2020/11/covid19-coronavirus-vaccine-health-distribution-equality.

15. Che Musa MF, Ghazali AB. Penemuan vaksin bukan lesen abai SOP, norma baharu. Berita Harian. 2021.

16. Watt RG, Sheiham A. Integrating the common risk factor approach into a social determinants framework. Community Dent Oral Epidemiol. 2012;40(4):289-96. 